\title{
Clinical application of FR-860 to hemodialysis: Multicenter cooperative study in Japan
}

Kazuo Ota, Toshiaki Suzuki, Shinji Naganuma, Kazuo Takahashi, Hiroshi Sekino*1, Seinosuke Nakagawa*2, Yoshindo Kawaguchi*3, Shozo Koshikawa*4, Tadao Akizawa*4, Hiroomi Kojima*4, Eriko Kinugasa*4, Hiroshi Nihei, Osamu Otsubo*5, Keihachiro Kuzuhara*5, Michio Odaka*6, Toshitsune Shimada*7, Noriaki Matsui*8, Yoshihei Hirasawa*9, Sachio Takahashi*9, Yutaka Kannou*10, Akira Saito*11, Hiroshi Ogawa*11, Masao Nakagawa*12, Katsunori Sawada*12, Masanobu Maekawa*13, Takeshi Sugimura*13

Tokyo Women's Medical College ; Kojin-kai Centran Hospital*1 ; Tokyo Tama Metropolitan Geriatric Medical Center*2 ; The Jikei University School of Medicine ${ }^{* 3}$; Showa University Fujigaoka Hospital $^{* 4}$; Toranomon Hospital ${ }^{* 5}$; Chiba University School of Medicine ${ }^{* 6}$; Chiba Social Insurance Hospital $^{* 7}$; Tsuchiura Kyodo Hospital ${ }^{* 8}$; Shinrakuen Hospital ${ }^{* 9}$; Aizawa Hospital ${ }^{* 10}$; Shinseikai Dai-Ichi Hospital ${ }^{* 11}$; Kyoto Prefectural University of Medicine ${ }^{* 12}$; Osaka City University, Medical School*13

key words: FR-860, low molecular weight heparin, anticoagulant, hemodialysis, chronic renal failure 〈Abstract〉

A multicenter cooperative study was designed to evaluate the efficacy and safety of FR-860 as an anticoagulant in hemodialysis. Sixty-five stable maintenance hemodialysis patients were enrolled into the study from fourteen institutions in Japan. 4 cases were excluded from the efficacy analysis because of protocol deviation (a violation of the concomitant drugs). The period of the study was fixed at two weeks. Dosage requirements were $15.0 \sim 20.0$ anti-Xa units/kg as a bolus and 7.5 10.0 anti-Xa units/kg/hr for continuous hourly administration. Total dosage of FR-860 (F) was 2,505 \pm 127 anti-Xa units compared to that of a conventional heparin (CH) dose of $6,124 \pm 190$ units. No difference in the residual blood in the extracorporeal circuit was observed between the $F$ and $\mathrm{CH}$ groups. The hemostatic time at the puncture site after the completion of dialysis was significantly shortened in the $\mathrm{F}$ group $(7.9 \pm 0.7 \mathrm{~min})$ in comparison with the $\mathrm{CH}$ group $(11.4 \pm 1.1 \mathrm{~min} ; \mathrm{p}<0.01)$. The plasma anti-Xa levels were $0.24 \pm 0.03$ and $0.36 \pm 0.04$ units $/ \mathrm{ml} 1 \mathrm{hr}$ after the initiation and at the completion of dialysis, respectively. ACT, measured by the Hemochron method, was not prolonged during dialysis. APTT varied from $34.3 \pm 1.2$ before dialysis to $41.0 \pm 1.9(p<0.01) 1 \mathrm{hr}$ after the start of dialysis and $39.9 \pm 1.6 \mathrm{sec}(p<0.01)$ at the end of dialysis. Plasma AT III activity increased from $96.8 \pm 2.5$ before dialysis to $113.0 \pm 3.2 \%(p<0.01)$ at the end of dialysis. No significant changes were observed in either ADP- or collagen-induced platelet aggregation during dialysis. Dialysis efficiency in the $\mathrm{F}$ group was similar to that in the $\mathrm{CH}$ group. Slight itching developed in one of the 65 cases. No abnormal laboratory data were observed during the study.

In conclusion, FR-860 was demonstrated to be a convenient alternative to conventional heparin as an anticoagulant in hemodialysis treatment.

Introduction

Hemodialysis requires anticoagulants to prevent fibrin deposition and thrombus formation in the extracorporeal circuit. Heparin has been used as a conventional anticoagulant in this field for a long time $^{1}$. Recently, many complications of heparin after

Kazuo Ota Department of Surgery, Kidney Center, Tokyo Women's Medical College 8-1 Kawada-cho, Shinjuku-ku, Tokyo 162, Japan Tel. 03-3353-8111 (Received for publication February 1, 1991 and in revised form February 20, 1991] 
the long-term usage have been documented. They include platelet dysfunction ${ }^{2)}$, thrombocytopenia ${ }^{3)}$, potential lipid abnormalities ${ }^{4}$, allergic reactions, alopecia and osteoporosis ${ }^{5}$. However, the major problem associated with heparin usage is the deteriorated risk of hemorrhage it imposes upon patients who already have a bleeding tendency secondary to uremia $^{6}$. For this reason, we have waited for the advent of a new alternative anticoagulant to heparin.

Low molecular weight heparin (LMWH) is a candidate for this purpose. In 1976, Andersson et al. ${ }^{7)}$ found that this LMWH fractions, which essentially lacked the ability to prolong the clotting time, were quite capable of potentiating the inhibition of coagulation factor Xa. Fragmin ${ }^{\circledR} \quad$ (FR-860), produced by nitrous acid depolymerization of unfractionated heparin in Kabi Vitrum, Stockholm, Sweden, is a product of LMWH fragment with average molecular weight of $4,400 \sim 5,600$ daltons. It has potential advantages over conventional unfractionated heparin for clinical use. They include higher specificity of antithrombotic action possibly without an increased risk of bleeding ${ }^{8)}$, less influence on platelet function ${ }^{2,3,9)}$ and on lipid metabolism $^{10 \sim 12)}$.

In this paper, a multicenter cooperative study was designed to evaluate the efficacy and safety of FR-860 as an anticoagulant in hemodialysis treatment.

\section{Materials and methods}

\section{Patients}

Between January 27 and April 11, 1987, sixty-five stable maintenance hemodialysis patients were enrolled into the study from fourteen institutions in Japan. 4 cases were excluded from the efficacy analysis because of protocol deviation (a violation of the concomitant drugs). They were 34 males and 27 females, aged at $50.5 \pm 1.60$ (mean \pm SEM) years. Body weight of the patients were $52.6 \pm 1.08$ (mean \pm SEM) $\mathrm{kg}$. The cause of end-stage renal disease was chronic glomerulonephritis in 46 patients, diabetic nephropath$\mathrm{y}$ in 4 patients, polycystic kidney disease in 4 patients, nephrotic syndrome in 2 patients, unknown origin in one patient and others in 4 patients. The following patients were excluded from the study : the patients 1) at high risk of bleeding or with active bleeding lesions, 2) in pregnancy or suspected to be pregnant and 3) with the age of less than fifteen years. The

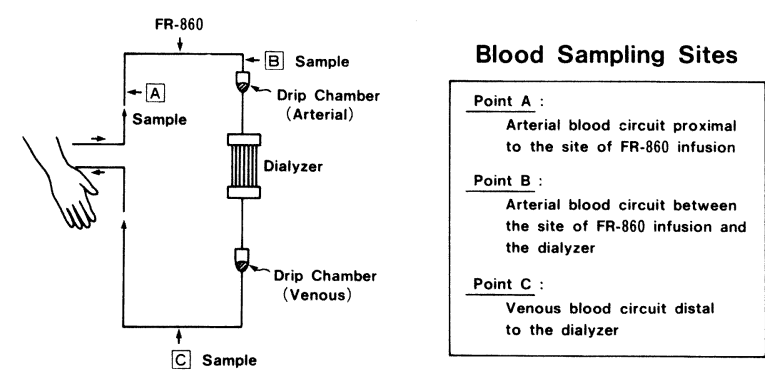

Fig. 1 Schematic diagram of extracorporeal blood circuit during hemodialysis procedure. FR-860 was administered at the site (behind arterial blood chamber) at the dose of 20 anti-fXa units/ $\mathrm{kg}$ as bolus plus 10 anti-fXa units $/ \mathrm{kg} / \mathrm{hr}$ as hourly continuous infusion. Point $\mathrm{A}-\mathrm{C}$ are blood sampling sites for evaluating the effects of FR-860.

protocol was approved by the institutional review boards of the participating institutions, and informed consent was obtained from all patients who enrolled in the study.

\section{Hemodialysis}

They underwent regular hemodialysis treatment twice (4 patients) and three times (57 patients) weekly, for a mean dialysis period of $6.7 \pm 0.56$ (mean \pm SEM) years. Each dialysis time was $4.6 \pm 0.03$ (mean \pm SEM) hrs. Extracorporeal blood (Qb) and dialysate flow rate $(\mathrm{Qd})$ were $188.2 \pm 1.27$ and $495.3 \pm 1.24$ (mean $\pm \mathrm{SEM}) \mathrm{m} l / \mathrm{min}$, respectively. Hollow fiber type dialyzers were used in all cases with the following membrane materials : cuproammonium rayon in 25 cases, polymethylmetacrylate (PMMA) in 18 cases, saponified cellulose in 11 cases, cellulose acetate in 4 cases, ethylenvynil alcohol (EVAL) in two cases and polyacrylonitril (PAN) in one case.

Preparation of FR-860 and its administration protocol

Preparation of FR-860, manufactured and supplied by Kissei Pharmaceutical Co., Ltd., Matsumoto, Japan, contains 10,000 anti-fXa units of low molecular weight heparin $\mathrm{Na}$ in one $\mathrm{m} l$ (one ampoule). FR-860 was administered at the site, behind arterial blood chamber, of extracorporeal blood circuit (Fig. 1) during hemodialysis procedure. Starting dose was 20.0 anti-fXa units (afXa U) $/ \mathrm{kg}$ as bolus, followed by hourly continuous infusion dose of $10.0 \mathrm{afXa} \mathrm{U} / \mathrm{kg} / \mathrm{hr}$. 
A corresponding dose adjustment was made based on the degree of residual blood in the dialyzer and blood clot in the drip chambers: When moderate to severe blood clotting (grade III to IV, described below) was observed, the dose was increased at the next dialysis session by either initial bolus of 5.0 afXa $\mathrm{U} / \mathrm{kg}$ or continuous infusion dose of 2.5 afXa $\mathrm{U} / \mathrm{kg} / \mathrm{hr}$. When two consecutive dialysis treatments were performed with no or slight blood clotting in the extracorporeal curcuit (grade I to II), the dose was decreased in the same way. The optimum dosage of FR-860 was then determined.

The controlled period with conventional (unfractionated) heparin was followed by the period of the study with FR-860, which was fixed in two weeks.

Assessment of residual blood and blood clot in blood circuit

The degree of residual blood in the dialyzer and blood clot in the drip chambers was observed macroscopically after each dialysis procedure and assessed with the following classification: I, no or a few (no or a few clot in the dialyzer or drip chambers) ; II, slight (a small amount of clot in the dialyzer or drip chambers) ; III, moderate (about half of fibers plugged by clots) ; IV, severe (difficult to continue extracorporeal circulation due to blood clotting in the dialyzer or drip chambers) .

\section{Laboratory methods}

Blood samples were collected from arterial and venous lines of blood circuit (Fig. 1) prior to, at 1 hour after the start of dialysis and immediately before the end of dialysis. Complete blood counts were obtained with Coulter counter. Blood chemistries were determined with an autoanalyzer. Plasma anti-fXa activity was assayed by an automated amidolytic method ${ }^{13)}$ using the chromogenic substrate S-2222, bovine factor $\mathrm{Xa}$ and human AT III concentrate (Daiichi Chemical Pharmaceutical Co., Ltd., Tokyo). Whole blood and activated coagulation time were measured with LeeWhite and Hemochron method, respectively. APTT and PT were assayed according to the manufacture's specifications. Antithrombin III (AT III) concentration was assayed immunochemically using Laurell's rocket technique and its activity was also determined amidolytically with the chromogenic substrate, S-2238 (Kabi Vitrum AB, Stockholm). Platelet aggregation

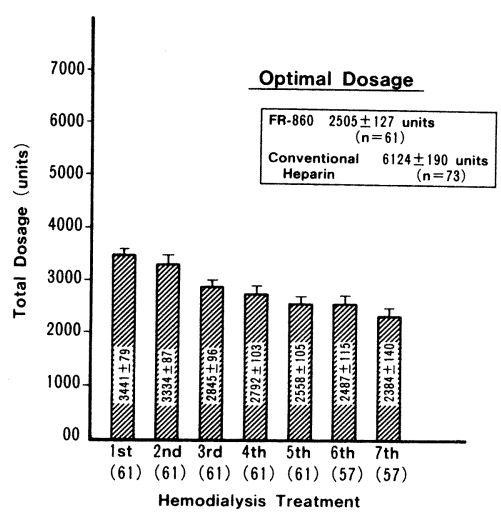

Fig. 2 Changes of total dosage of FR-860 during the study.

tests were performed with a NBS HEMA Tracer V Aggregometer, using 1.0, 3.0 and 100 microgram $/ \mathrm{m} l$ soluble bovine tendon collagen; 1.2, 2.5, 5.0, 10.0 and 50.0 micromole ADP.

Dialysis efficacy (reduction ratio of solutes) was calculated from the following equation.

Dialysis efficacy $(\%)=(1-$ post $-\mathrm{HD}$ value $/$ pre-HD value) $\times 100$

\section{Statistical Analysis}

The data were expressed as mean \pm SEM. The paired and unpaired Student's $t$ test were used for statistical analysis. Statistical significance was defined as a $P$ value of less than 0.05 .

\section{Results}

\section{Optimum dosage of FR-860}

Fig. 2 shows the changes of total dosage of FR- 860 during the study. The period of the study was fixed in two weeks. Total dosage of FR-860 decreased from $3,441 \pm 79$ at the 1 st hemodialysis treatment to $2,384 \pm$ 140 afXa $\mathrm{U}$ at the 7 th treatment. Optimum dosage of FR-860 was $2,505 \pm 127$ afXa $\mathrm{U}(\mathrm{n}=61)$ compared with that of conventional heparin of $6,124 \pm 190 \mathrm{U}(\mathrm{n}=$ 73). The distribution of optimum dosage of FR- 860 is shown in Fig. 3. Distribution of optimum dosage has three peaks : 10.0 afXa U/kg (bolus) plus 5.0 afXa U/ $\mathrm{kg} / \mathrm{hr}$ (continuous infusion) in 13 patients (21.3\%), 15.0 afXa $\mathrm{U} / \mathrm{kg}$ plus 7.5 afXa $\mathrm{U} / \mathrm{kg} / \mathrm{hr}$ in 14 patients $(23.0$ $\%$ ), and 20.0 afXa $\mathrm{U} / \mathrm{kg}$ plus 10.0 afXa $\mathrm{U} / \mathrm{kg} / \mathrm{hr}$ in 10 patients (16.4). It is also demonstrated that $91.8 \%$ of the patients could be dialyzed in a starting dose of FR -860 without any clotting problem in the extracopor- 


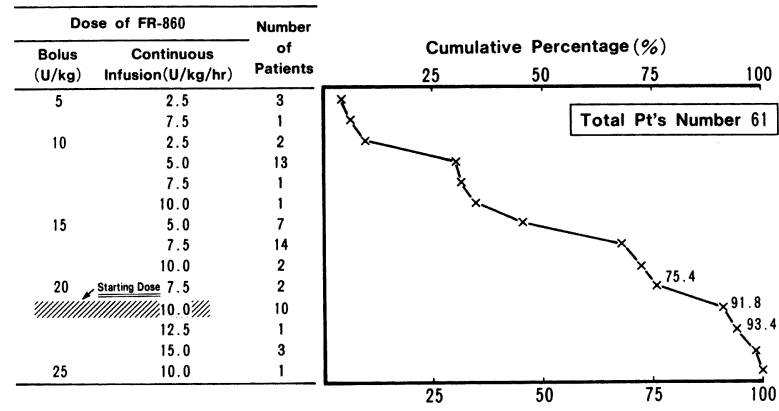

Fig. 3 The distribution of optimum dosage of FR-860. Starting dose was 20 anti-fXa units/kg as bolus plus 10 anti-fXa units $/ \mathrm{kg} / \mathrm{hr}$ as continuous infusion. The dosage was adjusted based on the status of blood clot in the drip chambers and residual blood in the dialyzer.

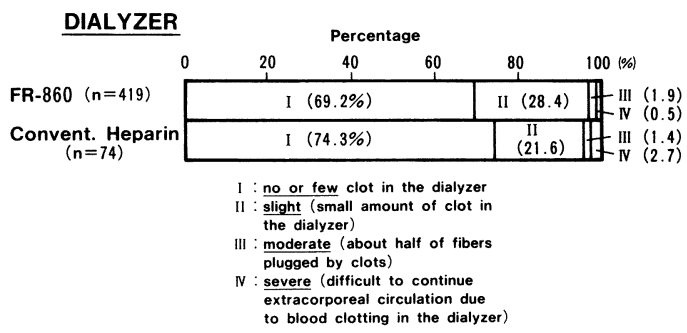

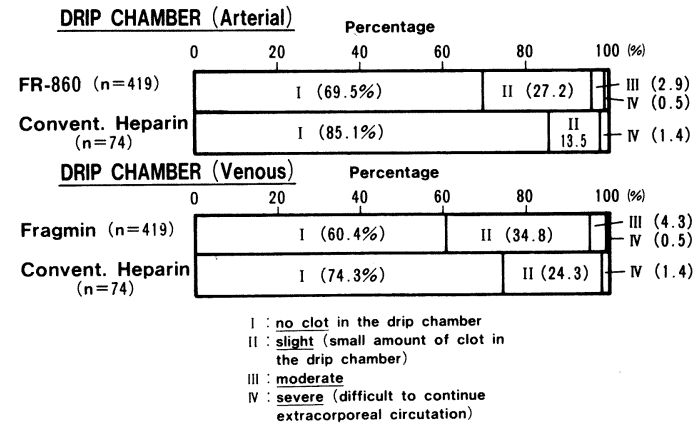

Fig. 4 The status of residual blood in the dialyzer and blood clot in the drip chambers.

eal blood circuit. Therefore optimum dosage was estimated to be $15.0 \sim 20.0$ afXa U/ $\mathrm{kg}$ as bolus plus 7.5 $\sim 10.0$ afXa $\mathrm{U} / \mathrm{kg} / \mathrm{hr}$ as hourly continuous infusion.

Residual blood and blood clot in blood circuit

Fig. 4 shows the status of residual blood in the dialyzer and blood clot in the drip chambers in both FR-860 and conventional heparin group. In both groups, about $95 \%$ of dialysis sessions could be perfor-

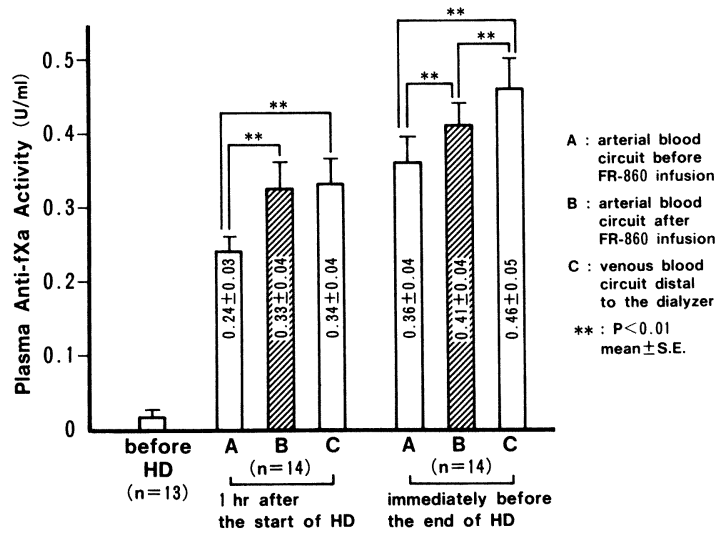

Fig. 5 Changes of plasma anti-fXa activity during hemodialysis with FR-860. Plasma anti-fXa level in the blood circuit (Point B) and in the systemic blood of patients (Point A) increased during dialysis.

med with a few or a small amount of clot in the dialyzer. No significant difference was observed between two groups. As shown in the lower part of Fig. 4, similar results in the drip chambers could be obtained to those in the dialyzer.

\section{Plasma anti-fXa activity}

Fig. 5 shows the changes of plasma anti-fXa activity during hemodialysis with FR-860. Plasma anti-fXa level in the blood circuit (Point B: arterial blood circuit after FR-860 infusion in Fig. 1) increased to $0.33 \pm 0.04$ units $/ \mathrm{m} l$ at $1 \mathrm{hr}$ after the start of dialysis and $0.41 \pm 0.04$ units $/ \mathrm{m} l$ immediately before the end of dialysis. Plasma anti-fXa level in the systemic blood of the patients (Point A : arterial blood circuit before FR-860 infusion) also increased to $0.24 \pm 0.03$ units $/ \mathrm{m} l$ at $1 \mathrm{hr}$ after the start of dialysis and $0.36 \pm 0.04$ units/ $\mathrm{m} l$ immediatelly before the end of dialysis.

\section{Blood coagulation time}

Fig. 6 shows the changes of coagulation parameters during dialysis with FR-860. ACT did not prolong during dialysis. But WBCT at Point A during dialysis prolonged compared with predialysis value $(548.3 \pm 24.0$ vs. $611.4 \pm 16.0 \mathrm{sec} /$ predialysis vs. $1 \mathrm{hr}$ after the start of dialysis ; $\mathrm{p}<0.05$ ). No significant changes in WBCT between Point A and Point B were observed.

\section{APTT and PT}

Fig. 7 shows the changes of APTT and PT during dialysis. APTT at Point A prolonged significantly 

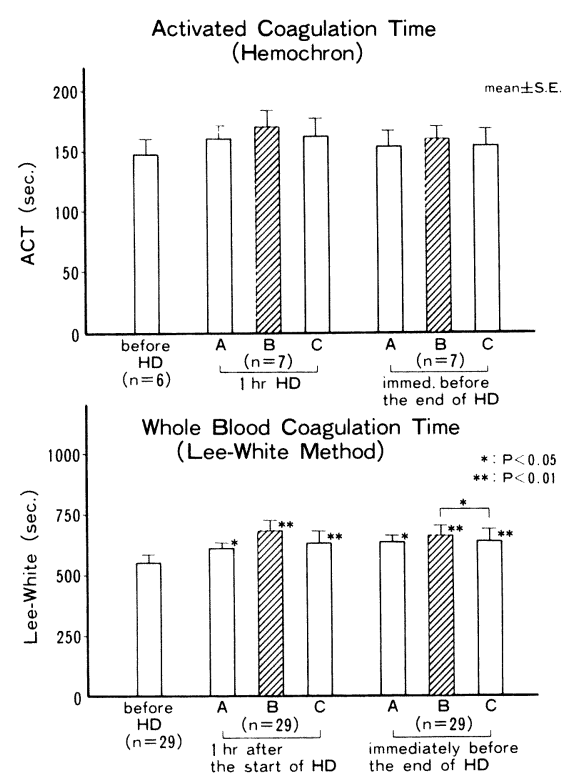

Fig. 6 Changes of coagulation parameters during hemodialysis with FR-860. Activated coagulation time (ACT) was not prolonged, but whole blood coagulation time (WBCT) at Point A during dialysis prolonged compared with predialysis value.

during dialysis from $34.3 \pm 1.2$ before dialysis to $41.0 \pm$ 1.9 seconds $(\mathrm{p}<0.01)$ at $1 \mathrm{hr}$ of dialysis. But the increment did not exceed 10 seconds over predialysis value. PT at Point $\mathrm{A}$ also prolonged significantly during dialysis $(12.0 \pm 0.2$ vs. $12.4 \pm 0.2$ seconds/predialysis vs. $1 \mathrm{hr}$ of dialysis; $\mathrm{p}<0.01)$. The increment did not exceed 2 seconds over predialysis value.

\section{Plasma AT III level}

Fig. 8 shows the changes of plasma AT III level during dialysis. Plasma AT III level was measured in both activity and concentration. Plasma AT III level increased only after dialysis. This phenomenon is suspected to result from the hemoconcentration after dialysis. There was no significant difference in plasma AT III level between before dialysis and $1 \mathrm{hr}$ after the start of dialysis.

\section{Platelet aggregation}

The changes of platelet aggregation during dialysis were investigated. There were no significant changes in both collagen- and ADP-induced platelet aggregation during dialysis.

The status of hemostasis at the puncture site

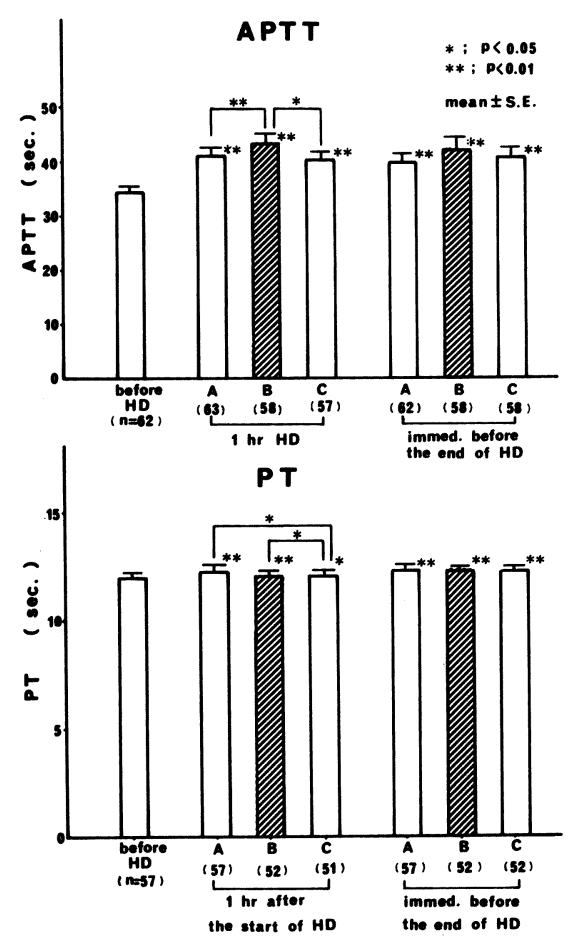

Fig. 7 Changes of activated partial thromboplastin time (APTT) and prothrombin time (PT) during hemodialysis with FR860.

The status of hemostasis at the puncture site of blood access was investigated after the end of hemodialysis. Hemostatic time at the use of FR- 860 was shortened in 265 out of 438 dialysis sessions ( 60.5 $\%)$ compared with that in conventional heparin. The distribution of hemostatic time at the puncture site is shown in Fig. 9. The peak of frequency in FR-860 group was observed at less than $5 \mathrm{~min}$, while observedetween 5 and $10 \mathrm{~min}$ in conventional heparin group. Hemostatic time in FR-860 group was significantly shortened compared with that in conventional heparin group $(7.9 \pm 0.7$ vs. $11.4 \pm 1.1 \mathrm{~min} ; \mathrm{p}<0.01)$.

\section{Side effects of FR- 860}

Slight itching developed in only one of 65 cases. No abnormal laboratory data was observed during the study.

\section{Discussion}

Heparin has been used as the most popular anticoagulant for hemodialysis, but its clinical use is limited by its major side effect, bleeding. Indeed, conventional systemic heparinization may lead to a 


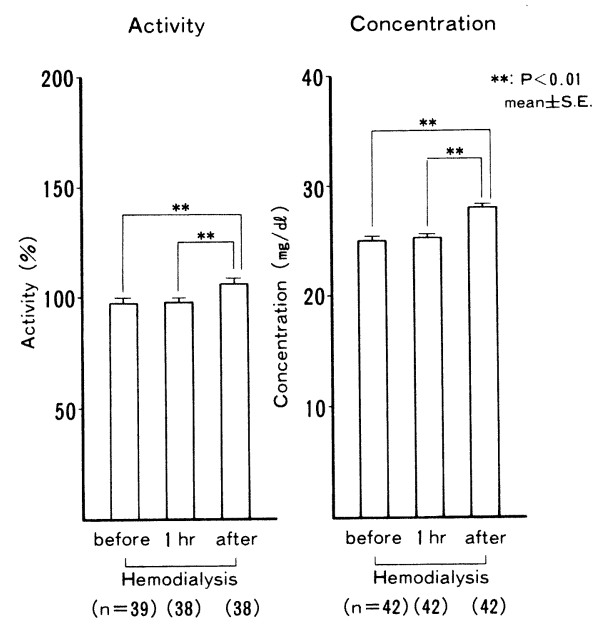

Fig. 8 Changes of plasma antithrombin III (AT III) level during hemodialysis with FR-860. Plasma AT III level increased after dialysis.

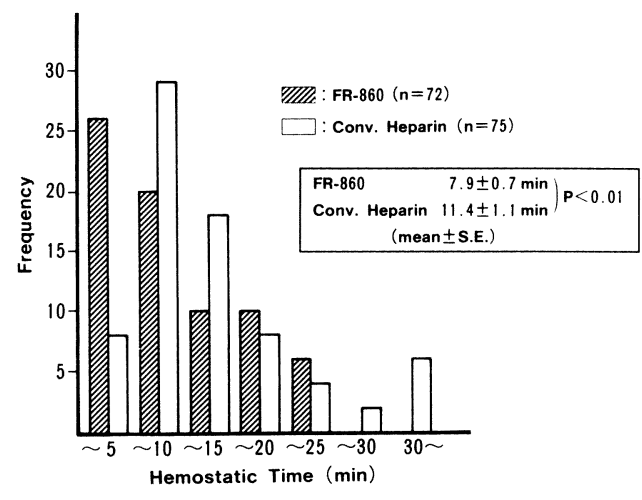

Fig. 9 Distribution of hemostatic time at the puncture site of blood access after the end of dialysis. Hemostatic time in FR860 group was significantly shortened compared with that in conventional heparin group.

life-threatening complication in some patients at high risk of bleeding. The hemorrhagic properties of heparin may be attributed to heparin per $\mathrm{se}^{7,8,14)}$ and the interaction with platelets ${ }^{2,15)}$.

The heparin preparations in clinical use today are heterogeneous with regard to molecular size. They consist of components with molecular weights ranging from 5,000 to 30,000 daltons. A molecular-size-dependency of the anticoagulant activity ${ }^{7,8,14}$ has been demonstrated by the studies on heparin fractions of different molecular weights obtained by gel filtration. They have shown that its anticoagulant activity is highly dependent on molecular weight. Thus, its ability to prolong the clotting time-measured by APTT test-declines sharply with decreasing molecular weight. On the other hand, the effects of heparin on the inhibition of factor $\mathrm{Xa}$ ( $\mathrm{fXa}$ ) differ from those observed with thrombin or expressed in the APTT. It was found that heparin fractions with very low molecular weights $(<3,000$ daltons $)$ ) had a limited ability to prevent experimental thrombosis in rabbit, while they exhibited a high anti-fXa activity. However, somewhat higher molecular weights $(4,400 \sim 5,600$ daltons ; LMWH) fractions produced at least as good an antithrombotic effect as conventional heparin without appreciably affecting the clotting time. Anti-fXa activity/APTT ratio for conventional unfractionated heparin was close to unity, but the ratio for LMWH fractions was two or more. It has been concluded that LMWH fractions possess antithrombotic properties (anti-fXa activity), but do not significantly prolong the clotting time (reduced antithrombin activity).

Another fascinating property of LMWH fractions is that they inhibit platelet aggregation less than conventional heparin ${ }^{2,3,9}$. These properties may lead to the conclusion that LMWH is a new promising alternative anticoagulant for hemodialysis. FR-860, produced by nitrous acid depolymerization of unfractionated heparin in Kabi Vitrum, Stockholm, Sweden, is a product of LMWH fragment with average molecular weight of 4,400 5,600 daltons.

The present study was performed in order to establish the efficacy and safty of FR-860 as an anticoagulant in hemodialysis treatment. Clinical study for healthy adult volunteers preceded this study. Sixty-five stable hemodialysis patients were enrolled in this study. And the patients at high risk of bleeding or with active bleeding lesions were excluded from eligible subjects for the study.

We tried to find the optimum dosage of FR-860 for hemodialysis procedure. Starting dose in the study was 20.0 asti-fXa units $/ \mathrm{kg}$ as initial bolus plus 10.0 anti-fXa units $/ \mathrm{kg} / \mathrm{hr}$ as hourly continuous infusion. The dose was adjusted based on the degree of residual blood in the dialyzer and blood clot in the drip chambers. On the basis of the dose-response relationship, 
the optimum dosage, which covered $91.8 \%$ of the patients, was estimated to be $15.0 \sim 20.0$ anti-fXa units $/ \mathrm{kg}$ as initial bolus plus $7.5 \sim 10.0$ anti-fXa units/ $\mathrm{kg} / \mathrm{hr}$ as hourly continuous infusion. Total optimum dosage of FR-860 was 2,505 \pm 127 anti-fXa units compared with that of conventional heparin of $6,124 \pm$ 190 units. It may be suggested that about 4 anti-fXa units of FR-860 has an equivalent antithrombotic activity to 10 units of conventional heparin.

The anti-fXa assay has been widely used for assessing the potency of LMWH fragments. Desired therapeutic level of anti-fXa activity, a level needed for keeping sufficient antithrombotic activity during longterm use, was reported to be above 0.5 units $/ \mathrm{m} l^{11,12,16}$. In our study, plasma peak anti-fXa activity at optimum dosage of FR- 860 was $0.41 \pm 0.04$ units $/ \mathrm{m} l$ immediately before the end of dialysis.

In regard to the changes of coagulation parameters during dialysis with FR-860, ACT did not prolong as expected. But WBCT and APTT prolonged during dialysis. Their increment was smaller than that in conventional heparin dialysis.

Of another interest in the study is to confirm the effects of FR-860 on platelet function. No significant changes in both collagen- and ADP-induced platelet aggregation was observed in conjunction with no changes in platelet counts (not shown in this text). This result is consistent with other reports ${ }^{11,12,16)}$.

One of potential advantages of FR- 860 is that it has higher specificity of antithrombotic action without bleeding. In order to clarify this issue, we investigated the status of hemostasis at the puncture site of blood access after the end of dialysis. Hemostatic time in FR860 group was significantly shortened compared with that in conventional heparin group. This evidence is important not only for patients but also for dialysis personnel from the practical point of view.

With regard to the effects of FR-860 on biochemical data and dialysis efficacy, we obtained suitable results compatible to those in conventional heparin dialysis. No abnormal laboratory data was observed during the study.

In conclusion, FR-860 was proven to be a good and convenient alternative to conventional heparin as an anticoagulant in hemodialysis treatment.
Acknowledments : We thank all colleagues and hospital personnels who took part for their efforts. We also acknowledge the valuable contribution of Mr. Hisao Suzuki and Mr. Yasuhiro Omori (Kissei Pharmaceutical Co., Ltd., Matsumoto, Japan).

\section{References}

1) Haas $G$ : Dialysieren des strömenden Blutes am Lebenden. Klin Wochenschr $70: 1888,1923$

2) Salzman EW, Rosenberg RD, Smith MH, Lindon JN, Favreau L : Effect of heparin and heparin fractions on platelet aggregation. J Clin Invest $65: 64-73,1980$

3) Kelton JG : Heparin-induced thrombocytopenia. Haemostasis $16: 173-186,1986$

4) Teraoka J, Matsui N, Nakagawa S, Takeuchi J : The role of heparin in the changes of lipid patterns during a single hemodialysis. Clin Nephrol $17: 96-99,1982$

5) Griffith MJ, Nichols G, Asher JD, Flanagan B : Heparin osteoporosis. JAMA 193 : 91-94, 1965

6) Gotti E, Remuzzi G : Uremic bleeding : Clinical presentation and management. In "Hemostasis and Kidney” ed., Remuzzi G, Rossi EC, p 131-141, Butterworths, London, 1989

7) Andersson L-O, Barrowcliffe TW, Holmer E, Johnson EA, Sims GEC : Anticoagulant properties of heparin fractionated by affinity chromatography on matrix bound antithrombin III and by get filtration. Thromb Res $9: 575-583$, 1976

8) Holmer E, Mattsson C, Nilsson S : Anticoagulant and antithrombotic effects of heparin and low molecular weight heparin fragments in rabbits. Thromb Res $25:$ 475-485, 1982

9) Holmer E, Lindahl U, Bäckström G, Thunberg L, Sandberg H, Söderström G, Andersson L-O : Anticoagulant activities and effects on platelets of a heparin fragment with high affinity for antithrombin. Thromb Res $18: 861-869,1980$

10) Persson E, Nordenström J, Nilsson-Ehle $P$, Hagenfeldt L : Lipolytic and anticoagulant activities of a low molecular weight fragment of heparin. Eur J Clin Inv $15: 215-220,1985$

11) Schrader J, Rieger J, Müschen $H$, Stibbe $W$, Köstering H, Kramer P, Scheler F : Anwendung 
von niedermolekularem Heparin bei Hämodialysepatienten. Klin Wochenschr 63 : 49-55, 1985

12) Schrader J, Stibbe W, Armstrong VW, Köstering $\mathrm{H}$, Scheler F : Comparison of low molecular weight heparin to standard heparin in hemodialysis/hemofiltration. Kidney Int $33: 890$ $-896,1988$

13) Teien AN, Lie M, Abildgaard U : Assay of heparin in plasma using chromogenic substrate for activated factor X. Thromb Res 8 : 413-420, 1976

14) Andersson L-O, Barrowcliffe TW, Holmer E, Johnson EA, Söderström G: Molecular weight dependency of the heparin potentiated inhibitor of thrombin and activated Factor X. Effect of heparin neutralization in plasma. Thromb Res $15: 531$ $-541,1979$

15) Kelton JG, Hirsh J : Bleeding associated with antithrombotic therapy. Semin Hematol $17: 375$ $-379,1980$

16) Lane DA, Ireland H, Flynn A, Anastassiades E, Curtis JR : Haemodialysis with kabi 2165 : Dosage requirements for the elimination of extracorporeal fibrin formation. Thromb Haemostasis $54: 320,1985$

\section{〈和文要旨〉}

血液透析における抗凝固剤としての低分子へパリン FR-860 有効性ならびに安全性について検討するため, 慢性腎 不全にて血液透析を受けている 65 名の患者を対象として全国 14 施設にわたる共同研究を行った。

本剤の至適投与量は透析開始時 $15 \sim 20$ 抗 Xa U/kg, 持続時 7.5 10 抗 Xa U/kg/hr であると判定された. 総投与 量では, 通常へパリン使用時が $6,124 \pm 190 U$ であったのに対して, FR-860 使用時では $2,505 \pm 127$ 抗 XaUであっ た。体外循環回路内残血の程度は，通常へパリン使用時とほぼ同様に，419 回の透析中 409 回 (97.6\%)で軽度以下で あり, 問題なく透析が実施できた。透析終了時の穿刺部止血状況については, 通常へパリン使用時に比較すると, $60.5 \%$

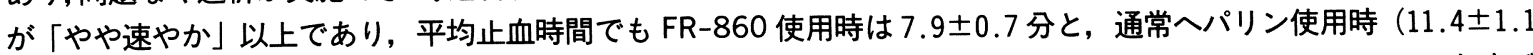
分）より明らかに短縮していた。透析中および終了時における血中抗 Xa 活性レベルは年れぞれ $0.24 \pm 0.03$ および $0.36 \pm 0.04 \mathrm{U} / \mathrm{ml}$ であった. 全血凝固時間の延長は, ACT を含む 5 種類のいずれの測定方法でも認められなかった. 血漿 AT III活性は，透析終了時に $96.8 \pm 2.5 \%$ から $113.0 \pm 3.2 \%$ に増加した. ADP およびコラーゲン誘発血小板凝集 に対する FR-860 の影響は認められなかった．本検討中臨床検査値の異常は認められず，また副作用としては軽度で 一過性の搔痒感が 1 症例に認められたのみであった。

以上の結果から, FR-860 は血液透析時の体外循環における抗凝固剤として通常ヘパリンに代わる, 極めて有効性 の高い薬剤であると結論が得られた。 